\title{
Origin-destination flows in chemotherapy for breast cancer in Brazil: implications for pharmaceutical services
}

\author{
Fluxos origem-destino para quimioterapia para o câncer de mama \\ no Brasil: implicações para a assistência farmacêutica
}

Mário Jorge Sobreira da Silva ${ }^{1}$

Enirtes Caetano Prates Melo ${ }^{2}$

Claudia Garcia Serpa Osorio-de-Castro ${ }^{3}$

${ }^{1}$ Coordenação de Ensino, Instituto Nacional de Câncer José Alencar Gomes da Silva. R. Marquês de Pombal 125, Centro. 20230-

130 Rio de Janeiro RJ Brasil.misobreira@

yahoo.com.br

${ }^{2}$ Departamento de

Epidemiologia e Métodos Quantitativos em Saúde

Escola Nacional de Saúde

Pública Sérgio Arouca

(ENSP), Fiocruz. Rio de

Janeiro RJ Brasil.

${ }^{3}$ Departamento de Políticas

de Medicamentos e

Assistência Farmacêutica,

ENSP, Fiocruz. Rio de

Janeiro RJ Brasil.

\begin{abstract}
This study maps and analyzes patient flows for breast cancer chemotherapy in order to identify the potential implications for organization of pharmaceutical services in the cancer care network. An ecological study design sought to correlate the place of residence with place of care for breast cancer patients. All chemotherapy procedures financed by Brazil's Unified Health System (SUS) and performed from January to December 2013 were included. Flows were mapped using TerraView ${ }^{\circ}$ software. A total of 1347803 outpatient chemotherapy procedures were delivered by 243 cancer care units located in 156 municipalities. Seventeen cities concentrated approximately $50.0 \%$ of the procedures. A total of 8538 origin-destination flows were generated and $49.2 \%$ of procedures were performed in services located outside the municipality in which the patient resided. Context challenges, related to inequality of access to chemotherapy and hindrances in planning and management of pharmaceutical services, were discussed.

Key words Pharmaceutical services, Healthcare delivery, Breast cancer, Spatial analysis, Health services accessibility
\end{abstract}

Resumo Este estudo mapeia e analisa os fluxos percorridos por pacientes em uso de quimioterapia para o tratamento do câncer de mama no Brasil, usando metodologia de redes, de forma a identificar potenciais implicações para a organização da assistência farmacêutica na rede de atenção oncológica. Realizou-se um estudo ecológico correlacionando o local de residência com o de atendimento de pacientes com câncer de mama. Incluiu-se todos os procedimentos de quimioterapia financiados pelo Sistema Único de Saúde (SUS), realizados no ano de 2013. O mapeamento dos fluxos foi efetuado no programa TerraView. Foram realizados 1.347 .803 procedimentos ambulatoriais de quimioterapia em 243 unidades habilitadas pelo SUS, sediadas em 156 municípios brasileiros. Dezessete cidades concentraram aproximadamente 50,0\% dos atendimentos. Foram gerados 8.538 fluxos de origem-destino e 49,2\% dos procedimentos foram realizados em serviços sediados fora do município de residência da mulher. Alguns aspectos da organização da assistência farmacêutica, relacionados a desigualdades no acesso à quimioterapia e dificuldades no planejamento de ações e serviços farmacêuticos foram problematizados frente ao contexto apresentado. Palavras-chave Assistência farmacêutica, Assistência à saúde, Câncer de mama, Análise espacial, Acesso aos serviços de saúde 


\section{Introduction}

Breast cancer is an important source of morbidity in Brazil ${ }^{1}$. It is the leading cause of cancer mortality and the most common neoplasm in women, except for non-melanoma skin cancer ${ }^{2}$. Breast cancer prevention and control are top health priorities in Brazil ${ }^{3}$.

Despite the adoption of a significant set of measures for breast cancer prevention and control, since the 1970s, the mortality rates in the country appear to have stabilized ${ }^{4-6}$. However, a relative increment has been observed in the survival time of women diagnosed with breast cancer, attributed to the incorporation of new drugs and other health technologies ${ }^{7}$. Although cancer patients' survival is related to time of diagnosis and staging of the disease, it is also largely associated with effective therapy, including pharmacotherapy, thus highlighting the importance of pharmaceutical services.

Pharmaceutical services are a complex process that involves multi-professional, interdisciplinary, and inter-sectorial activities, aimed at guaranteeing the availability and rational use of high-quality medicines ${ }^{8}$. Adequate organization of pharmaceutical services requires knowledge of the population's epidemiological, demographic, and economic profiles, analyzing need, access, equity, and drug utilization?.

In the context of cancer care, various components are necessary to guarantee an effective cancer care network, including pharmaceutical services, which should be organized according to a regional plan for comprehensive care of various types of cancers. Cancer care must also abide by rules for technology incorporation in Brazil's Unified Health System (SUS) ${ }^{10}$. Pharmaceutical services are viewed as a cross-cutting component, linked to other points of care in the health service network.

Local factors related to cancer patients and the health system, such as long distances between patients' homes and cancer care facilities, facilities' greater or lesser polarizing effect, bottlenecks in health service networks, and mechanisms for regulating patient flows have led to delays in cancer care, compromising access to treatment and its continuity, with impacts on survival time and mortality ${ }^{11-13}$.

Knowledge of the paths traveled by patients to receive chemotherapy can support planning strategic measures for restructuring care. The aim of this study is to map and analyze patient flows in chemotherapy for breast cancer treat- ment using a network methodology to identify potential obstacles to the organization of pharmaceutical services in the cancer care network.

\section{Method}

An ecological study was carried out to analyze outpatient chemotherapy in public and SUS-affiliated private health service facilities, certified by the Ministry of Health $(\mathrm{MOH})$ as one of three different types: 'high-complexity oncology center' (CACON), which gives comprehensive treatment to all types of cancers; 'high-complexity oncology center unit' (UNACON), that targets only the most prevalent cancer types, and includes at least chemotherapy and surgical services; or 'hospital complex-based oncology clinics' that only dispense chemotherapy to prevalent cancer types ${ }^{10}$. The study population consisted of women with principal diagnosis of breast cancer (subcategories C50.0 to C50.9 of the International Classification of Diseases, $10^{\text {th }}$ Revision - ICD10).

The study's data source was the 'Authorization for High-Complexity Procedures in Oncology' (APAC/Onco) registers, harbored in SUS' Ambulatory Care Information System (SIA-SUS). These registers are mandatory for chemotherapy and radiotherapy procedure payments to SUS providers ${ }^{14}$. The study included all chemotherapy procedures (encompassing traditional chemotherapy and hormone therapy) performed in the public and SUS-affiliated private health services facilities, from January to December 2013.

The data were aggregated by the breast cancer patients' municipality of residence and the municipality where chemotherapy was performed. The study did not identify individual patients, streets, or neighborhoods. Identification of the case's origin was based exclusively on the zipcode of the municipality of residence. Identification of the destination of breast cancer patients was based on the National Registry of Corporate Taxpayer Identification Numbers of the cancer care facilities and the zipcode for the corresponding municipality. The National Registry of Healthcare Establishments of SUS' Departament of Informatics (DATASUS) furnished the following data on cancer care facilities: type of facility (CACON, UNACON or hospital complex-based oncology clinics), nature of the organization (public or private), and type of establishment (general hospital, oncology or other). The study also identified the Brazilian state and the 'health 
region' (a group of municipalities not limited by state boundaries and characterized by the same social, cultural and economic identity $)^{15}$ in which the healthcare establishment was located.

An 'origin-destination pair' was defined, characterized by the link between place of residence (origin) and place of chemotherapy (destination). This pair was considered indivisible for the purposes of the current study and the line joining both ends expressed itself as a 'flow'.

Points of encounter for various destinations were characterized as 'nodes'. The interconnecting structures depicted by nodes, and by links between them, formed the 'health service network' for breast cancer. Network conformation focused on the 'dominant flow', representing the largest flow from a given origin (in this case the patient's municipality of residence). However, an accumulation of lines, resulting from the drawing of numerous links, complicated the identification of broad patterns. The problem was resolved by use of the system proposed by Oliveira et al. ${ }^{13}$, which provides identification of network conformation, based on the hierarchical structures proposed by Nystuen and Dacey ${ }^{16}$ : i) independent - if the dominant flow was from a larger city to a smaller city; ii) subordinate - if the dominant flow was from a smaller city to a larger city, and in this case no city could be subordinate to any of its subordinates; or iii) transitive - when city A was subordinate to $B$ and $B$ was subordinate to $C$, resulting in A subordinate to C. Mapping showed dominant flows, nodes and overall network conformation, representing the spatial interactions existing between origins and destinations ${ }^{17}$.

Flows are classified according to the direction, the hierarchy, and the health service network to which the flow belonged, resulting in a typology of relationships ${ }^{18}$, avoiding loss of information. In this analysis, hierarchy and flow direction were combined and resulted in 11 classification possibilities $^{19}$ (Chart 1). This study only incorporated into the health service network the municipalities of origin with a dominant flow greater than or equal to $5 \%$ of the total APAC/Onco authorizations for a given municipality.

Potential structural implications for health service networks, for regionalization and access to healthcare services, and for the organization of pharmaceutical services in oncology, specifically in relation to management, planning and logistics of drug supply, as well as drug selection and incorporation ${ }^{8,9}$ were identified.

DATASUS' Mortality Information System (SIM) furnished 2013 breast cancer mortality data for women. Other sources of relevant information were the scientific literature and relevant guidelines and rulings on breast cancer treatment.

Data tabulation and processing used the TabWin software, generating a matrix of flows between municipalities (origin-destination pairs) consisting of the number of APAC/Onco authorizations for chemotherapy procedures. The flows were mapped in TerraView ${ }^{ø}$ software using the flow plug-in.

All the information, software packages, and data used in the study are open-access. The study was approved by the Institutional Review Board of the Brazilian National School of Public Health (ENSP/Fiocruz).

\section{Results}

In the year 2013, 1347803 authorized traditional chemotherapy and hormone therapy procedures for women with breast cancer were financed by SUS. Hormone therapy is the most frequent of the two procedures, in all five Brazilian regions, but differences in proportions is small. For traditional chemotherapy, the national average was $21.2 \%$ (SD 3.2) and for hormone therapy $78.8 \%$ (SD 3.2). The procedures were performed in 243 public and SUS-affiliated private health services facilities located in 156 of Brazil's 5570 municipalities. Seventeen cities concentrated approximately $50.0 \%$ of the procedures. Table 1 shows the distribution of procedures according to the respective municipalities providing care and the percentage distribution of the municipal flows, in Brazil and in the health regions to which the municipalities belong.

Breast cancer patients seeking chemotherapy resided in 5069 municipalities. Healthcare establishments treated patients originating from a range of two to 561 different municipalities, with a mean of 55 municipalities $( \pm 45.1)$ and a median of 29.5 ( $S D=70.5)$. Twenty cities treated patients originating from more than 100 different municipalities and performed $48.1 \%$ of authorized procedures (Table 2).

Patients residing in 2278 municipalities ( $40.9 \%$ of all Brazilian municipalities) received chemotherapy in two or more different cities each. Ten municipalities, five in the state of São Paulo (Araras, Rio Claro, São Carlos, São Paulo and Tambaú), one in Goiás (Goiânia), one in the state of Minas Gerais (Itajubá), one in Paraná (Maringá), one in Acre (Rio Branco) and one in 
Chart 1. Typology of flows.

\begin{tabular}{|l|l|}
\hline \multicolumn{1}{|c|}{ Classification } & \multicolumn{1}{c|}{ Definition } \\
\hline Direct upward hierarchical & $\begin{array}{l}\text { The flow follows the network structure and the link goes to a node } \\
\text { at a higher hierarchical level. }\end{array}$ \\
\hline Short-circuit upward hierarchical & $\begin{array}{l}\text { The flow follows the network structure and the link goes to a node } \\
\text { at a higher hierarchical level but skips the closest hierarchical level. }\end{array}$ \\
\hline Direct downward hierarchical & $\begin{array}{l}\text { The flow follows the network structure and the link goes to a node } \\
\text { at a lower hierarchical level. }\end{array}$ \\
\hline Short-circuit downward hierarchical & $\begin{array}{l}\text { The flow follows the network structure and the link goes to a node } \\
\text { at a lower hierarchical level but skips the closest hierarchical level. }\end{array}$ \\
\hline Upward cross-cutting in the same network & $\begin{array}{l}\text { When the flow occurs between different branches in the same } \\
\text { network, going to a node at a higher hierarchical level. }\end{array}$ \\
\hline Upward cross-cutting between networks & $\begin{array}{l}\text { When the flow occurs between different networks, going to a node } \\
\text { at a higher hierarchical level. }\end{array}$ \\
\hline $\begin{array}{l}\text { Downward cross-cutting in the same } \\
\text { network }\end{array}$ & $\begin{array}{l}\text { When the flow occurs between different branches in the same } \\
\text { network, going to a node at a lower hierarchical level. }\end{array}$ \\
\hline $\begin{array}{l}\text { Downward cross-cutting between } \\
\text { networks }\end{array}$ & $\begin{array}{l}\text { When the flow occurs between different networks, going to a node } \\
\text { at a lower hierarchical level. }\end{array}$ \\
\hline $\begin{array}{l}\text { Horizontal cross-cutting in the same } \\
\text { network }\end{array}$ & $\begin{array}{l}\text { When the flow is internal to the network and connects nodes at } \\
\text { the same hierarchical level. }\end{array}$ \\
\hline $\begin{array}{l}\text { Horizontal cross-cutting between } \\
\text { networks }\end{array}$ & $\begin{array}{l}\text { When the flow occurs between different networks and connects } \\
\text { nodes at the same hierarchical level. }\end{array}$ \\
\hline Local link & When origin and destination coincide. \\
\hline
\end{tabular}

Adapted from Oliveira et al ${ }^{19}$.

the state of Rio de Janeiro (Rio de Janeiro), sent chemotherapy patients to more than seven other municipalities.

The public and SUS-affiliated private health service facilities were distributed across all Brazilian states and the Federal District, covering 143 $(32.6 \%)$ of the 436 health regions in the country. Five states, Minas Gerais, Paraná, Rio de Janeiro, Rio Grande do Sul and São Paulo, concentrated $65.6 \%$ of the procedures and 156 of the public and SUS-affiliated private health services facilities providing chemotherapy $(64.2 \%)$.

The majority of chemotherapy units were UNACONs, classified as non-profit private charities and registered as general hospitals (Table 3 ).

The process generated a total of 8538 origin-destination flows. The dominant flows totaled 4957 links and involved 1232899 procedures, of which 551952 were performed in healthcare establishments located outside the municipality in which the patient resided, thus characterized as external flows. Of these, the most intense flow totaled 8074 procedures.

According to the typology of relationships, nine of the 11 possible network flows were identified: i) local link (1.8\%); ii) direct upward hierarchical flows (62.8\%); iii) short-circuit upward hierarchical flows (11.0\%); iv) direct downward hierarchical flows (1.1\%); v) short-circuit downward hierarchical flows $(0.1 \%)$; vi) cross-cutting upward flows between networks (8.5\%); vii) cross-cutting downward flows between networks (1.0\%); viii) horizontal cross-cutting flows between networks (2.6\%); and ix) horizontal cross-cutting flows within the same network (11.1\%).

As for the volume of chemotherapy procedures, $50.8 \%$ were performed in the patient's municipality of residence, a highly-regionalized pattern, $45.5 \%$ were performed in other municipalities following the main network flow, and $3.7 \%$ were performed in different networks or between branches in the same network.

Ten municipalities presented most of the networks with local links, two in the state of São Paulo (Campinas and São Paulo), one in Bahia (Salvador), Ceará (Fortaleza), one in Mato Grosso do Sul (Campo Grande), one in Minas Gerais (Belo Horizonte), one in Paraná (Curitiba), one in Pernambuco (Recife), one in Rio de Janeiro (Rio de Janeiro) and one in the state of Rio Grande do Sul (Porto Alegre). They harbored $43.9 \%$ of chemotherapy procedures characterized by that type of flow.

Figure 1 shows the network flows. Either local links (Figure 1a) or the other kinds of flows (Fig- 
Table 1. Distribution of chemotherapy procedures for breast cancer treatment in the principal municipalities that performed care in Brazil, 2013.

\begin{tabular}{|c|c|c|c|c|c|c|}
\hline \multirow[t]{2}{*}{ Municipality (State ${ }^{a}$ ) } & \multirow{2}{*}{$\begin{array}{c}\text { Total } \\
\text { authorized } \\
\text { procedures }(\mathbf{n})\end{array}$} & \multicolumn{2}{|c|}{ Municipal flow (\%) } & \multicolumn{2}{|c|}{$\begin{array}{c}\text { Flow in the health } \\
\text { region }(\%)\end{array}$} & \multirow{2}{*}{$\begin{array}{c}\text { Brazil } \\
(\%)\end{array}$} \\
\hline & & Local & External & Local & External & \\
\hline São Paulo (São Paulo) & 142775 & 69.0 & 31.0 & 69.0 & 31.0 & 10.6 \\
\hline Rio de Janeiro (Rio de Janeiro) & 63731 & 64.6 & 35.4 & 86.9 & 13.1 & 4.7 \\
\hline Belo Horizonte (Minas Gerais) & 59878 & 49.1 & 50.9 & 56.9 & 43.1 & 4.4 \\
\hline Fortaleza (Ceará) & 55167 & 67.3 & 32.7 & 68.4 & 31.6 & 4.1 \\
\hline Salvador (Bahia) & 45919 & 52.4 & 47.6 & 57.7 & 42.3 & 3.4 \\
\hline Recife (Pernambuco) & 45252 & 34.0 & 66.0 & 71.9 & 28.1 & 3.4 \\
\hline Porto Alegre (Rio Grande do Sul) & 44025 & 40.1 & 59.9 & 54.6 & 45.4 & 3.3 \\
\hline Barretos (São Paulo) & 35417 & 5.6 & 94.4 & 11.5 & 88.5 & 2.6 \\
\hline Curitiba (Paraná) & 31081 & 57.7 & 42.3 & 81.3 & 18.7 & 2.3 \\
\hline Campinas (São Paulo) & 24705 & 38.0 & 62.0 & 73.1 & 26.9 & 1.8 \\
\hline Vitória (Espírito Santo) & 20534 & 15.4 & 84.6 & 68.7 & 31.3 & 1.5 \\
\hline Jaú (São Paulo) & 18854 & 7.5 & 92.5 & 17.3 & 82.7 & 1.4 \\
\hline Cascavel (Paraná) & 18486 & 25.3 & 74.7 & 36.5 & 63.5 & 1.4 \\
\hline Goiânia (Goiás) & 18359 & 49.1 & 50.9 & 56.4 & 43.6 & 1.4 \\
\hline Teresina (Piauí) & 17615 & 41.3 & 58.7 & 48.7 & 51.3 & 1.3 \\
\hline Natal (Rio Grande do Norte) & 17537 & 46.8 & 53.2 & 59.2 & 40.8 & 1.3 \\
\hline João Pessoa (Paraíba) & 16719 & 44.3 & 55.7 & 57.6 & 42.4 & 1.2 \\
\hline Brazil & 1347803 & 24.8 & 25.4 & 31.1 & 19.1 & 100.0 \\
\hline
\end{tabular}

${ }^{a}$ States of Brazil plus the Federal District.

Table 2. Municipalities that performed chemotherapy procedures for breast cancer patients originating from more than other 100 different cities. Brazil, 2013.

\begin{tabular}{lccc}
\hline \multirow{2}{*}{ Municipality (State ${ }^{\text {a }}$ ) } & $\begin{array}{c}\text { Number of municipalities } \\
\text { served (n) }\end{array}$ & \multicolumn{2}{c}{ Total authorized procedures } \\
\cline { 2 - 4 } Barretos (São Paulo) & 561 & 35417 & $(\%)$ \\
Salvador (Bahia) & 328 & 45919 & 3.6 \\
Belo Horizonte (Minas Gerais) & 312 & 59879 & 4.4 \\
Teresina (Piauí) & 240 & 17615 & 1.3 \\
São Paulo (São Paulo) & 239 & 142775 & 10.6 \\
Recife (Pernambuco) & 207 & 45252 & 3.4 \\
Goiânia (Goiás) & 200 & 18359 & 1.4 \\
Jaú (São Paulo) & 198 & 18854 & 1.4 \\
Porto Alegre (Rio Grande do Sul) & 193 & 44025 & 3.3 \\
João Pessoa (Paraíba) & 167 & 16719 & 1.2 \\
Fortaleza (Ceará) & 160 & 55167 & 4.1 \\
Natal (Rio Grande do Norte) & 150 & 17537 & 1.3 \\
Cascavél (Paraná) & 149 & 18486 & 1.4 \\
Campinas (São Paulo) & 146 & 24705 & 1.8 \\
Curitiba (Paraná) & 123 & 13245 & 2.3 \\
São Luís (Maranhão) & 122 & 10629 & 1.0 \\
Cuiabá (Mato Grosso) & 118 & 9696 & 0.8 \\
Muriaé (Minas Gerais) & 113 & 10600 & 0.7 \\
Passo Fundo (Rio Grande do Sul) & 108 & 12427 & 0.8 \\
Bento Gonçalves (Rio Grande do Sul) & 102 & & 0.9 \\
\hline
\end{tabular}

${ }^{a}$ States of Brazil. 
Table 3. Characteristics of Brazilian healthcare establishments that performed chemotherapy procedures for women with breast cancer in 2013.

\begin{tabular}{|c|c|c|}
\hline \multirow{2}{*}{ Characteristics of healthcare units } & \multicolumn{2}{|c|}{ Number } \\
\hline & $(\mathbf{n})$ & $(\%)$ \\
\hline \multicolumn{3}{|l|}{ Type of Facility } \\
\hline $\mathrm{CACON}^{\mathrm{a}}$ & 19 & 7.8 \\
\hline CACON with pediatric oncology service & 24 & 9.9 \\
\hline $\mathrm{UNACON}^{\mathrm{b}}$ & 79 & 32.5 \\
\hline UNACON with hematology service & 15 & 6.2 \\
\hline UNACON with pediatric oncology service & 6 & 2.5 \\
\hline UNACON with radiotherapy service & 45 & 18.5 \\
\hline UNACON with hematology and pediatric oncology services & 9 & 3.7 \\
\hline UNACON with hematology and radiotherapy services & 28 & 11.5 \\
\hline UNACON with pediatric oncology and radiotherapy services & 3 & 1.2 \\
\hline UNACON with hematology, pediatric oncology, and radiotherapy services & 12 & 4.9 \\
\hline Hospital Complex-Based Oncology Clinic & 3 & 1.2 \\
\hline \multicolumn{3}{|l|}{ Nature of Organization } \\
\hline Direct health administration - Federal & 8 & 3.3 \\
\hline Direct health administration - State & 26 & 10.7 \\
\hline Direct health administration - Municipal & 4 & 1.6 \\
\hline Direct administration by other agencies - Federal & 6 & 2.5 \\
\hline $\begin{array}{l}\text { Indirect administration - Federal (independent agency, public corporation, public } \\
\text { foundation) }\end{array}$ & 9 & 3.7 \\
\hline $\begin{array}{l}\text { Indirect administration - State (independent agency, public foundation, public } \\
\text { social organization) }\end{array}$ & 10 & 4.1 \\
\hline Indirect administration - Municipal (independent agency, public foundation) & 8 & 3.3 \\
\hline Private corporation & 20 & 8.2 \\
\hline Non-profit charitable organization & 149 & 61.3 \\
\hline Other (private foundation, autonomous social service) & 3 & 1.2 \\
\hline \multicolumn{3}{|l|}{ Type of Establishment } \\
\hline Oncology & 27 & 11.1 \\
\hline General Hospital & 206 & 84.8 \\
\hline $\begin{array}{l}\text { Other (specialized in cardiology, maternity hospital, orthopedics, emergency, clinic } \\
\text { specialties center, notification clearinghouse, uptake, and distribution of agencies) }\end{array}$ & 10 & 4.1 \\
\hline
\end{tabular}

ure $1 \mathrm{~b}$ to $1 \mathrm{f})$ are concentrated in the northeastern coast and in the Brazilian South and Southeast, especially in the state of São Paulo. The links appearing in the Southeast and South (two of Brazil's five geographic regions) were basically of the hierarchical type, while the North and Northeast of the country showed many cross-cutting networks, with flows directed mainly to the Southeast and South.

The median distance from the patient's place of residence to the public or SUS-affiliated private health service facility performing chemotherapy procedures was $103.9 \mathrm{~km}(\mathrm{SD}=291.0)$, with a mean of $188.4 \mathrm{~km} .94 .7 \%$ of the procedures were performed within this mean distance. However, patients from 4023 Brazilian municipalities had to travel more than $50 \mathrm{~km}$ for care, while 2727 procedures $(0.2 \%)$ were performed more than $1000 \mathrm{~km}$ from the patient's place of residence. In 498 municipalities (68.3\% of which in the North or Northeast) there was no record whatsoever of referral for breast cancer chemotherapy.

The year 2013 recorded 14206 breast cancer deaths in women residing in 5569 Brazilian municipalities. The three states with the highest mortality rates, adjusted by age for the world population and Brazil, were Rio de Janeiro, Rio Grande do Sul, and São Paulo. Most deaths $(75.8 \%)$ occurred in health regions with at least one public or SUS-affiliated private health service 


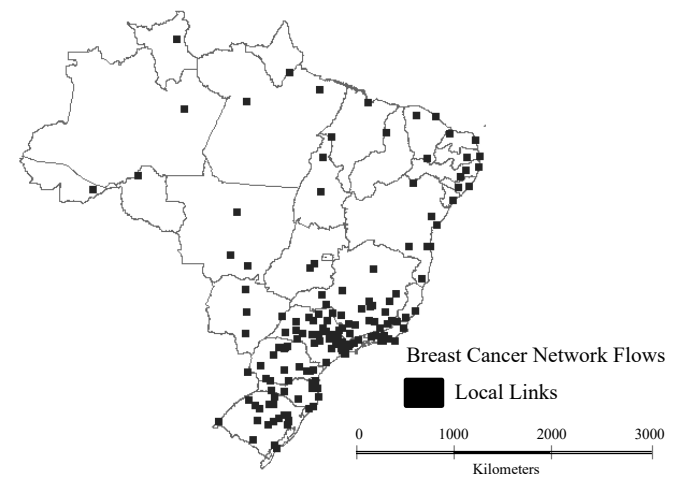

1.a) Local links a

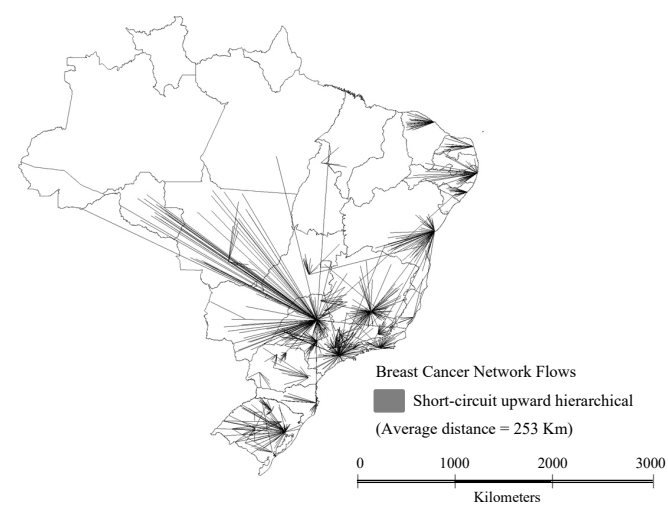

1.c) Short-circuit upward hierarchical ${ }^{c}$

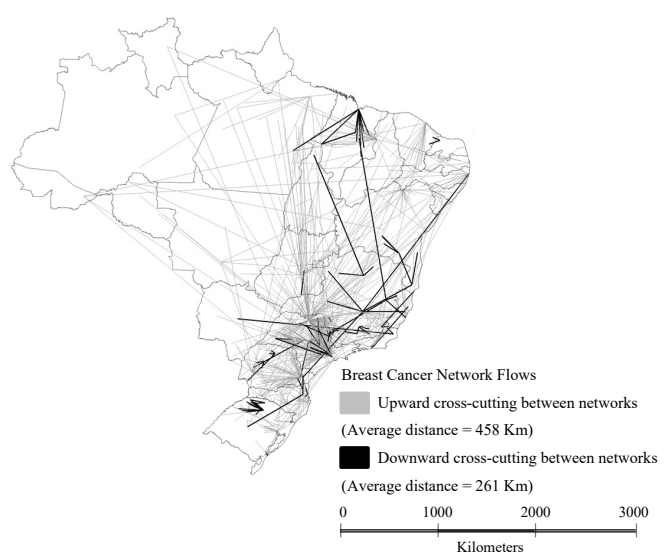

1.e) Upward cross-cutting between networks ${ }^{\mathrm{f}}$ and Downward cross-cutting between networks ${ }^{g}$

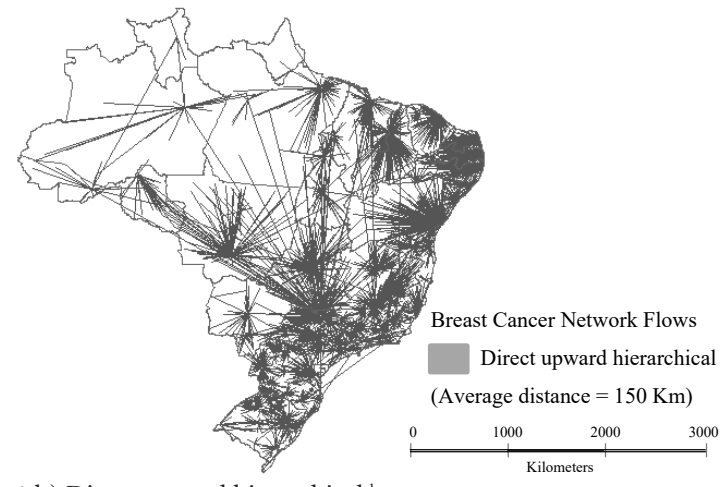

1.b) Direct upward hierarchical ${ }^{\text {b }}$

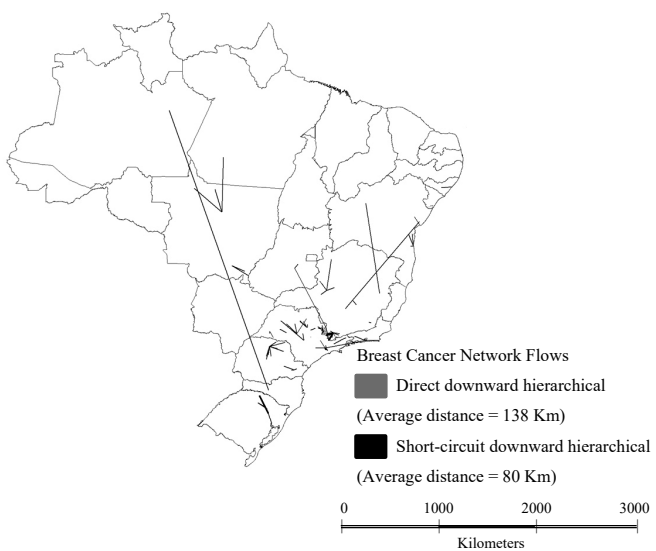

1.d) Direct downward hierarchical ${ }^{\mathrm{d}}$ and Short-circuit downward hierarchical ${ }^{\mathrm{e}}$

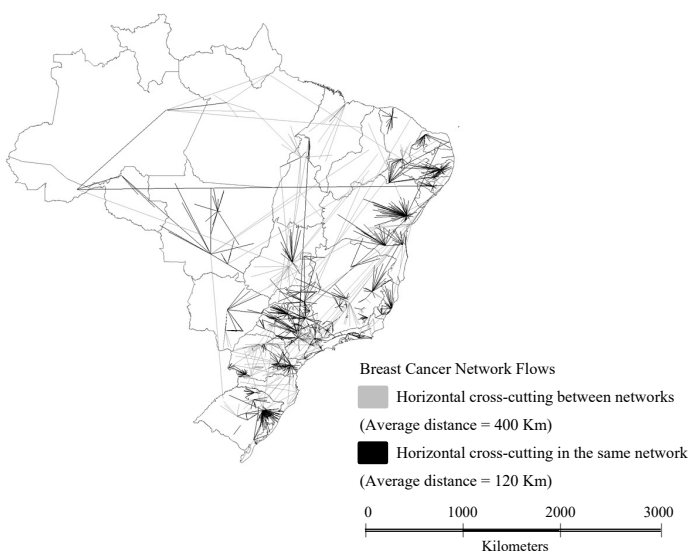

1.f) Horizontal cross-cutting between networks ${ }^{\mathrm{h}}$ and Horizontal cross-cutting in the same network ${ }^{\mathrm{i}}$

Figure 1. Conformation of network flows for chemotherapy procedures for breast cancer in Brazil, according to typology of relationships, in 2013.

${ }^{\mathrm{a}}$ Local link - when origin and destination coincide; ${ }^{\mathrm{b}}$ Direct upward hierarchical flows - follow the network structure and the link goes to a node at a higher hierarchical level; c Short-circuit upward hierarchical flows - follow the network structure and the link goes to a node at a higher hierarchical level but skips the closest hierarchical level; ${ }^{\mathrm{d}}$ Direct downward hierarchical flows - follow the network structure and the link goes to a node at a lower hierarchical level; e Short-circuit downward hierarchical flows - follow the network structure and the link goes to a node at a lower hierarchical level but skips the closest hierarchical level; ${ }^{\mathrm{f}}$ Upward cross-cutting flows between networks - when the link occurs between networks, going to a node at a higher hierarchical level; ${ }^{g}$ Downward cross-cutting flows between networks - when the link occurs between networks, going to a node at a lower hierarchical level; ${ }^{\mathrm{h}}$ Horizontal cross-cutting flows between networks - when the link occurs between different networks and connects nodes at the same hierarchical level; i Horizontal cross-cutting flows in the same network - when the link is internal to the network and connects nodes at the same hierarchical level. 
facility performing chemotherapy procedures. Among the municipalities that did not send any chemotherapy patients to other municipalities, there were 41 deaths from breast cancer.

\section{Discussion}

The study identified representative chemotherapy origin-destination flows for women with breast cancer, in 2013, and viewed cancer treatment occurring in SUS health service networks. The study included all the procedures financed by the public system, as well as practically all the providers (public and SUS-affiliated private health services facilities) treating breast cancer.

Chemotherapy is the most prevalent cancer treatment modality in the cancer care network. The study showed an increase in supply of chemotherapy in public and in SUS-affiliated private health services facilities and in number of destination municipalities, since 2005-2006, when cancer care network flows for breast cancer treatment were mapped for the first time ${ }^{13}$. Most network flows were of the 'direct upward hierarchical' type, concurring with previous results ${ }^{13}$.

However, the 2013 data showed increment in the number of chemotherapy procedures in municipalities other than place of residence $(3.8 \%$ increase) and in the average distance between place of residence and place of treatment (3.4 $\mathrm{km}$ increase). Previously identified problems apparently persist, such as the concentration of facilities in a limited number of municipalities, alongside the existence of empty spaces in terms of breast cancer treatment in the country ${ }^{13}$. Such aspects may compromise the accessibility of breast cancer patients to chemotherapy.

Considering healthcare regionalization, the principle of comprehensiveness, and the fact that chemotherapy is a highly-complex procedure, one can expect that services will not be available in all Brazilian municipalities, but that at least in one in each health region. However, the study showed that the public and SUS-affiliated private health services facilities were only present in $32.6 \%$ of the country's health regions. Chemotherapy services were concentrated in $2.8 \%$ of Brazil's municipalities. Although they were available in all the states and the Federal District, $64.2 \%$ of the services were located in five states in the South and the Southeast, which are home to approximately $21.7 \%$ of the Brazilian population, revealing an important mismatch in the distribution of services in the country's territory.
This evidence suggests difficulties in the organization of comprehensive care for breast cancer patients, including patient referral mechanisms and potentially for planning and management of pharmaceutical services.

As the results show, a greater percentage of procedures happened near the patient's home, characterizing a regionalized pattern. However, the mapping of flows showed a broad variation in healthcare availability in Brazil. There are relatively few municipalities for patients to go seeking care (156), considering the large number of municipalities of origin (5 570). The results corroborate other studies showing that breast cancer patients are more likely to access the supply of services when the place of residence and place of treatment coincide. These studies also associate better access with higher human development index (HDI) ${ }^{6,20,21}$. Flow types were also characteristic of each geographic region. In the South and Southeast, because of the greater number of providers, flows are mostly hierarchical, which signifies that they follow the network structure. The system may be more able to function as it should with patient referral mechanisms in place. In the North and Northeast, because of less availability of care facilities, cross-cutting flows, not obeisant to network structure are found.

Regional voids, mainly characterized by groups of small municipalities, mostly located in the North and Northeast regions, reflect difficulties in health system organization. Breast cancer deaths were identified in these locations, permitting the assumption that these municipalities may have also harbored untreated cases.

In 2013, approximately 53000 new cases of breast cancer were expected in Brazil (estimated incidence of 52/100 000 women $)^{22}$. However, estimations for each of the country's $5570 \mathrm{mu}$ nicipalities are lacking. Therefore, it is practically impossible to plan the service needs for each municipality.

When observing the origin-destination flows, some issues pose challenges for the organization of pharmaceutical services. The first is the number of patients coming from 5069 different municipalities that are treated in the hub cities of only 156 health regions. Although the flow of care is mostly local or regional, it is challenging to measure the chemotherapy needs in the respective health region's non-resident patient population. The large number of municipalities that formed two or more different links (2 278) and the large amount of cross-cutting flows confirm this situation. 
In breast cancer, lack of access to treatment can result in worse prognosis, higher relapse rate, and increased mortality. Studies have demonstrated that lack of medicines in public services jeopardizes the treatment of chronic diseases, including cancer ${ }^{12,23-25}$. Thus, lack of knowledge on treatment needs and volume of care can make pharmaceutical services potentially ineffective, considering that such information influences the planning and logistics of drug supply. The organization of hierarchical health services networks and the adoption of planning strategies would help solve issues involved in the quality of cancer care $^{26,27}$.

Pharmaceutical services should also be planned in connection to other necessary forms of care for cancer patients, towards comprehensive care. Many breast cancer treatment protocols involve chemotherapy and radiotherapy. According to the Brazilian data, most public and SUS-affiliated private health service facilities that performed chemotherapy lacked radiotherapy services $^{13}$. The spatial fragmentation of therapeutic activities tends to decrease treatment adherence, since patients must follow distinct flows to have all their needs met.

The organization of pharmaceutical services in oncology is complex, considering that patients may need intravenous or oral chemotherapy, that in turn require the use of a variety of other drugs to control symptoms and adverse reactions related to the treatments ${ }^{28}$. According to the findings, most of the procedures authorized for the treatment of breast cancer were for hormone therapy $(78.8 \%)$. This aspect reveals the need to structure dispensing activities that can guarantee safety and effectiveness in hormone use, as well as to contribute to treatment adherence. In the same way, there is need to provide safe and effective procedures for compounding of chemotherapeutic drugs, for which training of pharmacists in oncology is essential.

One issue places additional constraints on the management of pharmaceutical services. Despite nominal adoption of certification criteria ${ }^{29}$ by treatment facilities, breast cancer treatment is not strictly covered by a full Clinical Protocol and Treatment Guideline in Oncology, but by a Diagnostic and Treatment Guideline, which issues information on best evidence and suggests therapy but does not link treatment with pre-established clinical criteria ${ }^{30}$. Thus, even though admitting that protocol adherence may be frail ${ }^{31}$, it is not possible to guarantee the use of the Ministry of Health's Clinical Protocol and Treatment Guide- line in Oncology (PCDT-Onco) as the source of the best treatment option, or, therefore, to rely on availability of the technologies approved by the National Commission for the Incorporation of Technologies in the Unified Health System (CONITEC) $^{32}$.

Twenty-one applications for oncology medicines were made to CONITEC between July 2012 and July 2015 resulting in 12 incorporations ${ }^{32}$. Currently, a total of 12 adjuvant (prophylactic) procedures, three pre-chemotherapy neoadjuvant/cytoreductive and four palliative chemotherapy procedures are authorized by SUS for breast cancer treatment ${ }^{30}$. However, it is worth mentioning that 'chemotherapy procedures', which include drugs, are actually a reimbursement package scheme and not a therapeutic plan. Disclosure of individual costs incurred with medicines are practically impossible ${ }^{33}$. Considering that knowledge of costs of medicines is a crucial factor for the organization of the pharmaceutical services, this aspect is revealed as another challenge to be overcome.

There is a limited number of specialized cancer treatment facilities. The presence of specialized health care teams favors planning and care, expanding the quality and effectiveness of treatment outcomes ${ }^{34,35}$. One may expect that institutions not specialized in oncology will carry a list of drugs different from the one in specialized facilities, causing wide variability in treatment approaches. Brazil also lacks an established medicines list for cancer. The current National List of Essential Medicines (Rename) ${ }^{36}$ fails to include antineoplastic agents. The scenario reveals inequalities in therapeutic strategies, potentially compromising both the management of pharmaceutical services and patient outcomes ${ }^{37,38}$.

Chemotherapy involves not only sequential sessions, but also the need for patient follow-up due to adverse effects ${ }^{39-41}$. For breast cancer patients, this means considering the number of sessions and the total treatment time, which can reach 60 months $^{30}$. In this context, the distance travelled to obtain care may even determine whether the patient completes or abandons treatment $^{21,42}$. Despite current government measures such as financial assistance for patients undergoing treatment away from home $\mathrm{e}^{43}$ and the use of elective health transportation ${ }^{10}$, there is nevertheless observable inequality in access to services. This study showed that half of the procedures performed were for residents of the 156 municipalities that housed the public and SUS-affiliated private health services facilities, and that in 
$72.2 \%$ of the procedures performed away from the woman's home municipality, the distance travelled was greater than $50 \mathrm{~km}$.

Paradoxically, the expansion in treatment supply, considering the increase in the number of public and SUS-affiliated private health service facilities performing chemotherapy, and the incorporation of new technologies, appears to have had no effect on breast cancer mortality. According to the data, the highest breast cancer mortality rates were in locations with chemotherapy supply, and most deaths occurred in health regions with at least one $\mathrm{MOH}$-certified chemotherapy service. This information may be viewed in relation to the quality of services being supplied.

Four important study limitations deserve mention. Our results were based on information registered by the system but relayed by the patient. Accuracy regarding patient domiciles may be compromised if data were falsely informed. However, conclusions as to overall patient migration hold and stress the need to organize services in destination municipalities. The data that were used to map flows refer to the procedures, not the patients. It is not possible to establish correlations with data on continuity of treatment, or to measure treatment adherence versus dropout. The flows portray the distance and not the actual path travelled by patients in search of treatment, which can be a long sinuous. Use of the procedure as a measure further implies the actual performance of chemotherapy, but does not rule out other forms of access to therapy.

Although the option to map only chemotherapy procedures might limit analysis of the cancer care network, the examination served as a proxi for pharmaceutical services in oncology and helped reveal important barriers that have not been discussed in previous studies, demonstrating the relevance of focused analyses when studying complex structures such as health service networks.

Analysis of the network formats contributes to organization and planning of health systems, strengthening healthcare services and optimizing the performance. Progress was observed after mapping chemotherapy flows for breast cancer. However, there are numerous barriers to the implementation of pharmaceutical services. Understanding and overcoming these challenges are essential for obtaining further progress, contributing to more efficient use of resources for cancer control in Brazil.

\section{Collaborations}

MJS Silva participated in study conception and planning, data analysis and interpretation, and drafting of manuscript; ECP Melo participated in study conception and planning, data analysis and critical revision of manuscript; and, CGS Osorio-de-Castro participated in study conception and planning, data analysis and interpretation, and critical revision of manuscript. All authors approved the version to be published. 


\section{References}

1. Leite IC, Valente JG, Oliveira AF, Santos MF, Rodrigues RN, Daumas RP, Schramm JMA, Silva RS, Campos MR, Mota JC. Carga de doença no Brasil e suas regiões, 2008. Cad Saude Publica 2015; 31(7):1551-1564.

2. Instituto Nacional de Câncer José Alencar Gomes da Silva (INCA). Estimativa 2016: incidência de câncer no Brasil. Rio de Janeiro: INCA; 2015.

3. Brasil. Ministério da Saúde (MS). Plano de ações estratégicas para o enfrentamento das doenças crônicas não transmissiveis (DCNT) no Brasil 2011-2022. Brasília: MS; 2011.

4. Hashim D, Boffetta P, La Vecchia C, Rota M, Bertuccio P, Malvezzi M, Negri E. The global decrease in cancer mortality: trends and disparities. Ann Oncol 2016; 27(5):926-933.

5. Porto MAT, Teixeira LA, Silva RCF. Aspectos históricos do controle do câncer de mama no Brasil. Rev Brasileira Cancerologia. 2013; 59(3):331-339.

6. Rodrigues JD; Cruz MS; Paixão AN. Uma análise da prevenção do câncer de mama no Brasil. Cien Saude Colet 2015: 20(10):3163-3176.

7. Guerra MR, Silva GA, Nogueira MC, Leite ICG, Oliveira RVC, Cintra JRD, Bustamante-Teixeira MT. Sobrevida por câncer de mama e iniquidade em saúde. Cad Saude Publica 2015; 31(8):1673-1684.

8. Correr CJ, Otuki MF, Soler O. Assistência farmacêutica integrada ao processo de cuidado em saúde: gestão clínica do medicamento. Rev Pan-Amaz Saúde 2011; 2(3):41-49.

9. Luz TCB, Mosegui GBG. Epidemiologia e assistência farmacêutica. In: Osorio-de-Castro CGS, Luiza VL, Castilho SR, Oliveira MA, Jaramillo NM, organizadores. Assistência Farmacêutica: gestão e prática para profissionais de saúde. Rio de Janeiro: Editora Fiocruz; 2014. p. 307-323.

10. Brasil. Portaria GM/MS n..$^{\circ} 874$, de 16 de maio de 2013. Institui a Política Nacional para a Prevenção e Controle do Câncer na Rede de Atenção à Saúde das Pessoas com Doenças Crônicas no âmbito do Sistema Único de Saúde (SUS). Diário Oficial da União 2013; 17 maio.

11. Freitas AGQ, Weller M. Patient delays and system delays in breast cancer treatment in developed and developing countries. Cien Saude Colet 2013; 20(10):3177-3189.

12. Medeiros GC, Bergmann A, Aguiar SS, Thuler LCS. Análise dos determinantes que influenciam o tempo para início do tratamento de mulheres com câncer de mama no Brasil. Cad Saude Publica 2015; 31(6):12691282.

13. Oliveira EXG, Melo ECP, Pinheiro RS, Noronha CP, Carvalho MS. Acesso à assistência oncológica: mapeamento dos fluxos origem-destino das internações e dos atendimentos ambulatoriais. O caso do câncer de mama. Cad Saude Publica 2011; 27(2):317-326.

14. Brasil. Ministério da Saúde (MS). Manual de Bases Técnicas - SIA/SUS - Sistema de Informações Ambulatoriais. Brasília: MS; 2016.

15. Brasil. Presidência da República. Decreto n. ${ }^{\circ} 7.508$, de 28 de junho de 2011. Regulamenta a Lei n. ${ }^{\circ} 8.080$, de 19 de setembro de 1990, para dispor sobre a organização do Sistema Único de Saúde - SUS, o planejamento da saúde, a assistência à saúde e a articulação interfederativa, e dá outras providências. Diário Oficial da União $2011 ; 29$ jun.
16. Nystuen JD, Dacey MF. A graph theory interpretation of nodal regions. Papers in Regional Science 1961; $7(1): 29-42$.

17. Ferreira MC. Iniciação à análise geoespacial: teoria, técnicas e exemplos para geoprocessamento. São Paulo: Editora Unesp; 2014.

18. Rabino GA, Occelli S. Understanding spatial structure from network data: theoretical considerations and applications. Cybergeo: European Journal of Geography [on line], document 29, published June 26, 1997. [cited 30 Nov 2015]. Available at: http://cybergeo.revues. org/2199

19. Oliveira EXG, Silveira Junior JC, Souza-Santos R, Pina MF, Portugal JL. Análise de dados espaciais. In: Santos SM, Souza-Santos R, organizadores. Sistema de informações geográficas e análise espacial na saúde pública. Brasília: Ministério da Saúde (MS); 2007. p. 63-80.

20. Sadovsky ADI, Poton WL, Reis-Santos B, Barcelos MRB, Silva ICM. Índice de Desenvolvimento Humano e prevenção secundária de câncer de mama e colo do útero: um estudo ecológico. Cad Saude Publica 2015; 31(7):1539-1550.

21. Wan S, Jubelirer S. Geographic access and age-related variation in chemotherapy use in elderly with metastatic breast cancer. Breast Cancer Res Treat 2015; 149(1):199-2019.

22. Instituto Nacional de Câncer José Alencar Gomes da Silva (INCA). Estimativa 2012: incidência de câncer no Brasil. Rio de Janeiro: INCA; 2011.

23. Katrein F, Tejada CAO, Restrepo-Méndez, MC, Bertoldi AD. Desigualdade no acesso a medicamentos para doenças crônicas em mulheres brasileiras. Cad Saude Publica 2015; 31(7):1416-1426.

24. Souza JA, Hunt B, Asirwa FC, Acetamido C, Lopes G. Global health equity: cancer care outcome disparities in high-, middle-, and low-income countries. J Clin Oncol 2015; 34(1):6-13.

25. Ruff P, Al-Sukhun S, Blanchard C, Shulman LN. Access to Cancer Therapeutics in Low-and Middle-Income Countries. In: American Society of Clinical Oncology educational book/ASCO. Chicago: American Society of Clinical Oncology; 2016. p. 58-65.

26. Jesus WLA, Assis MMA. Revisão sistemática sobre o conceito de acesso nos serviços de saúde: contribuições do planejamento. Cien Saude Colet 2010; 15(1):161170.

27. Vieira FS. Avanços e desafios do planejamento no Sistema Único de Saúde. Cien Saude Colet 2009; 14(Supl. 1):1565-1577.

28. Broadfield L, Shaheen P, Rogez M, Jamieson K, McCallum M. Guidelines for outpatient cancer care by community pharmacists. Canadian Pharmacists Journal 2017; 150(1):24-31.

29. Ministério da Saúde (MS). Portaria n. ${ }^{\circ} 140$, de 27 de fevereiro de 2014. Redefine os critérios e parâmetros para organização, planejamento, monitoramento, controle e avaliação dos estabelecimentos de saúde habilitados na atenção especializada em oncologia e define as condições estruturais, de funcionamento e de recursos humanos para a habilitação destes establishments no âmbito do Sistema Único de Saúde (SUS). Diário Oficial da União 2014; 28 fev. 
30. Brasil. Ministério da Saúde (MS). Secretaria de Atenção à Saúde. Portaria n. ${ }^{\circ}$ 1.008, de 30 de setembro de 2015. Aprova as diretrizes diagnósticas e terapêuticas do carcinoma de mama. Diário Oficial da União 2015; 1 out.

31. Lin HY, Bedrosian I, Babiera GV, Shaitelman SF, Kuerer HM, Woodward WA, Ueno NT, Shen Y. Using the National Cancer Data Base for quality evaluation to assess adherence to treatment guidelines for nonmetastatic inflammatory breast cancer. Cancer 2017; 123(14):2618-2625.

32. Gadelha MIP, Martins SJ, Petramale CA. Oncologia desfechos e experiências da Comissão Nacional de Incorporação de Tecnologias no Sistema Único de Saúde. Gestão e Saúde 2015; 6(Supl. 4):3194-3212.

33. Vieira FS, Zucchi P. Financiamento da assistência farmacêutica no Sistema Único de Saúde. Saúde Soc 2013; 22(1):73-84.

34. Ramos MCA, Cruz LP, Kishima VC, Pollara WM, Lira ACO, Couttolenc BF. Avaliação de desempenho de hospitais que prestam atendimento pelo sistema público de saúde, Brasil. Rev Saúde Pública. 2015; 49:43.

35. Taplin SH, Weaver S, Salas E, Chollette V, Edwards HM, Bruinooge SS, Kosty MP. Reviewing Cancer Care Team Effectiveness. J Oncol Pract 2015; 11(3):239-246.

36. Brasil. Ministério da Saúde (MS). Relação Nacional de Medicamentos Essenciais: Rename 2014. Brasília: MS; 2015.

37. Robertson J, Barr R, Shulman LN, Forte GB, Magrini N. Essential medicines for cancer: WHO recommendations and national priorities. Bull World Health Organ 2016; 94:735-742.

38. Cuomo RE, Mackey TK. The availability of essential cancer medication: An analysis of national formularies. Journal of Cancer Policy 2017; 12:49-54.

39. Brito C, Portela MC, Vasconcellos MTL. Fatores associados à persistência à terapia hormonal em mulheres com câncer de mama. Rev Saude Publica 2014; 48(2):284-295.
40. Gunaldi M, Duman BB, Afsar CU, Paydas S, Erkisi M, Kara IO, Sahin B. Risk factors for developing cardiotoxicity of trastuzumab in breast cancer patients: an observational single-center study. J Oncol Pharm Practice 2016; 22(2):242-247.

41. Neugut AI, Hillyer GC, Kushi LH, Lamerato L, Leoce $\mathrm{N}$, Ambrosone CB, Bovbjerg DH, Mandelblatt JS, Hershman DL. Non-initiation and early discontinuation of adjuvant trastuzumab in women with localized HER2-positive breast cancer. Breast Cancer 2014; 21(6):780-785.

42. Ward MM, Ullrich F, Mattews K, Rushton G, Tracy R, Bajorin DF, Goldstein MA, Kosty MP, Bruinooge SS, Hanley A, Lynch CF. Access to Chemotherapy Services by Availability of Local and Visiting Oncologists. J Oncol Pract 2014; 10(1):26-31.

43. Ministério da Saúde (MS). Portaria n. ${ }^{\circ}$ 55, de 24 de fevereiro de 1999. Dispõe sobre a rotina do Tratamento Fora de Domicílio no Sistema Único de Saúde - SUS, com inclusão dos procedimentos específicos na tabela de procedimentos do Sistema de Informações Ambulatoriais do SIA/SUS e dá outras providências. Diário Oficial da União 1999; 25 fev.

Artigo apresentado em 24/12/2016

Aprovado em 14/06/2017

Versão final apresentada em 16/06/2017 